\title{
The Family-School Relationships in Europe: A Research Review
}

PAOLA DUSI ${ }^{1}$

$\approx$ The literature on research carried out in the field and parents' and teachers' declarations all point in the same direction: good collaboration between home and school is useful to the child-student for his education and learning. Despite this, parent-teacher relationships in Europe (and elsewhere), from Spain to Sweden, from Ireland to Greece, and from Italy to the Czech Republic, represent an unresolved issue. This is a complex relationship that calls into play various social spheres: macro (social), intermediary (institutional) and micro (relational); in fact, there are as many diverse realities as there are schools. In Europe, the relationship between individual behaviours (parents vs. teachers), social orientations (neoliberalism) and institutional frameworks (school markets) appears significant: scarce parental participation, lack of adequate forms of home-school communications, and the need to make investments in parent and teacher training. Nevertheless, family and school are called on to create a dialogue in order to contribute to the processes of training new generations. They both need each other in order to carry out that task in the best way. This paper presents and discusses the results of a theoretical analysis conducted on the basis of the international literature concerning research on the school-family relationship, with particular attention on the situation of different European countries, and concludes with suggestions for some practical improvements.

Keywords: Benefits and difficulties, European perspective, Individual behaviour, Institutional frameworks, School-family relationship, Social orientations

1 University of Verona, Department of Philosophy, Pedagogy and Psychology Lungadige Portavittoria 17 - 37129 Verona (Italy) paola.dusi@univr.it 


\section{Odnos med družino in šolo v Evropi - pregled raziskav}

PaOla Dusi

$\propto$ Literatura, povezana $\mathrm{z}$ raziskavami na področju sodelovanja med domom in šolo, ter izjave staršev in učiteljev kažejo, da je tovrstno sodelovanje koristno za učenčevo vzgojo in izobraževanje. Kljub temu v Evropi (in drugod) - od Španije do Švedske, od Irske do Grčije in od Italije do Češke - ostaja vprašanje odnosa med starši in učitelji nerešeno. Gre za kompleksen odnos, ki vključuje različne socialne sfere: makro (družbeno), srednjo (institucionalno) in mikro (odnosno). Pravzaprav gre za toliko različnih stvarnosti, kolikor je šol samih. V Evropi se kot pomemben kaže odnos med vedenji posameznih akterjev (starši : učitelji), socialno usmerjenostjo (neoliberalizem) in institucionalnimi okviri (izobraževalni trg); participacija staršev je skromna, komunikacija med šolo in domom nezadostna, potrebno je vlaganje v usposabljanje staršev in učiteljev. Kljub temu sta družina in šola poklicani $\mathrm{k}$ vzpostavljanju dialoga, da bi prispevali k procesu usposabljanja novih generacij. Druga drugo potrebujeta za čim boljše uresničevanje njunih nalog. Prispevek predstavlja izsledke teoretične analize, izvedene na osnovi mednarodne literature s področja odnosov med družino in šolo, s posebnim poudarkom na prikazu stanja različnih evropskih držav in $\mathrm{v}$ sklepu poda predloge za izboljšave $\mathrm{v}$ praksi.

Ključne besede: odnos med šolo in družino, vedenje staršev in učiteljev, institucionalni okviri, socialna usmerjenost, koristi in težave, evropska perspektiva 


\section{Introduction}

Research carried out in the field, and the extant literature almost all point in the same direction (Swap, 1993). A good relationship between family and school means that the student can be provided with a better training programme, i.e. one which helps the student experience the encounter of these two worlds in a calm way. Both teachers' professionalism and the parents' knowledge of their child can pave the way to an efficacious educational partnership.

It is to be emphasized, however, that the related literature often conveys a 'romantic' vision of the family-school relationship, highlighting only the positive effects that parent-teacher collaboration can create while overlooking the inevitable differences that this brings out, such as the fatigue and patience required by teachers, as well as ignoring the risks and excesses (in terms of interference and/or being overwhelmed) that collaboration can also cause (Casanova, 1996). Parents and teachers often live in a state of a 'desire for peace and quiet' that, in practice, can transform into a pact of non-interference. Educational limits of respective competences are not a fait accompli, since the marginal areas of these spaces in which parents and teachers carry out their responsibilities and functions have an irregular, uncertain form and are intertwined with wider-reaching social-cultural dynamics. Family-school relationships are not exempt from the dynamics of power that are part and parcel of human relationships (Foucault, 1998). Respect, recognition and trust encounter contempt, repudiation and lack of trust (Honneth, 1992) to create essentially subtle conflicts of power (social and personal), even when teachers and parents meet (Henry, 1996). There are a myriad of factors at play. Nonetheless it is the teachers' task, given that they are professionals, to identify suitable strategies to handle the inevitable contrasts that collaborative relationships and rapports create. Promoting dialogue with parents does not mean merely looking for consensus; it means allowing for confrontation, reflecting on various points of view and creating a dialogue with perspectives that are often in contrast.

However, both teachers and parents, when asked, state they believe that mutual collaboration is useful to both education and learning.

This paper takes as a starting point the hypothesis that the school-family relationship is intrinsically difficult due to the complex nature of the educational role, whatever the socio-cultural and normative framework is. As a consequence, the main objective of this study is to provide a wider vision of the family-school relationship by taking into account the European perspective and to find out whether there are recurring elements that characterize the essence of this kind of relationship. The paper collects together and present transversal 
aspects found in the literature, which form the structure of the family-school relationship in the different countries with regards to parental participation, teachers' attitudes and the benefits that a good family-school relationship brings with it on various levels. One of the findings from this analysis is the correlation that exists between individual behaviour (parents), institutions (schools) and a neoliberal and market orientation (nations and continent) that characterize the family-school relationship at the European level. An analysis of the literature has led to the possibility of making some suggestions to improve the familyschool relationship, an objective that is shared by policies of various national contexts. Criteria used for selection of the literature were: papers focusing on the school-family relationship (primary school) in European countries, the significance of the contribution, and the date of publication.

\section{The Home-School Relationship and Parental Characteristics}

Many studies have highlighted the fact that parents want to be more involved in the educational processes of their children and receive more information and help from schools in order to be able to be involved (Baker \& Stevenson, 1986; Bastiani, 1993; Comer, 1988; Dauber \& Epstein, 1989; GonzálezFalcón \& Romero-Muñoz, 2011; Migeot-Alvarado, 2002). However, there are others who believe that their duty to school is to pay the taxes that permit public services, including schools, to function properly; others think that participating in school life is not one of these duties; while yet others are so overwhelmed by their own jobs, families and economic considerations that they are unable to take part in any type of social activity.

Why, in fact, are parents not very involved in their children's schooling? For an infinite number of reasons, every one of which brings a piece of reality with it, in its complexity: from time to energy, from economic resources to a lack of familiarity with the school system, from the knowledge of curriculum to trust in the true ability to be of help to one's child; from convictions regarding what parenting means and to the functions related to the changing ages of the child and personal experience of a parent's own schooling and with teachers.

Parental characteristics that influence the school-home relationships in a relevant way can be summarized as follows (adapted from Eccles \& Harold, 1996):

1. Parents' social and psychological resources (personal health, available coping strategies, social networks);

2. Personal sense of efficacy (trust in one's own ability to help children 
carry out assigned tasks; a conviction of being able to continue helping one's children in various subjects during secondary school);

3. Perception of one's own child (trust in the child's cognitive and learning abilities; educational and job hopes, and expectations for one's child; real opportunities for one's child in the present and future);

4. Parent's personal construction of the parental role; convictions regarding parental role in children's education and results obtained at school (What is the parent's role? How does this role change during a child's growth? Attribution or not of importance in participating in management of school, benefits that good school performance creates);

5. Cultural, ethnic and religious identity of parents (perception of one's own culture, religion and socialization processes; existing relationships between cultural convictions, parental role and school results; cultural and social recognition received in the school context; school perceived as a reality in which models and values are provided that contrast with those of the family or a context in which one is helped in the task of cultural and religious transmission);

6. Parental socialization practices (carrying out of their educational role in order to promote their children's autonomy and independence; presence or absence of sharing and reworking through children's experiences);

7. History of relationship with school and education of children (their prior experience in school and relationships with teachers; introduction to the school system as a parent and continuation of this relationship during the course of their children's scholastic career).

Studies carried out in different European (and non-European) countries all identify a various array of competing factors that determine parents' positions concerning school. These positions, however, together with the way in which teachers act on the relationship with families, have a determining role.

\section{Teachers' Visions of the Family-School Relationship}

According to a great deal of research, the way in which a relationship between a student's family and an educational institution takes shape, depends mostly on how the institution and its professionals carry out their roles. The family-school relationship is influenced by the practices adopted by teachers, by the structure of the educational institution, and the way in which a family is considered by the school; it also depends on teachers and their interest level and desire to involve parents, and on their knowledge of concrete methods 
aimed at increasing processes of parental collaboration.

The passivity of parents observed in various European countries seems to be fuelled by the formal and institutional nature of the school, by its bureaucracy and the attitudes of many teachers who do not always encourage the presence of parents. At the international level, a widespread state of paradoxical behaviour at school has also been seen between teachers towards parents who are the end receivers of these contradictory messages. The latter are told: 'You are absent parents, therefore inadequate', but at the same time, the parents are also asked 'not to be overly present' (Auduc, 2007; Gayet, 1999; González-Falcón \& Romero-Muñoz, 2011). Teachers, as a matter of fact, do not seem to encourage the involvement of parents at school and in the classroom, especially when they are dealing with low-income families and/or members of a minority, who are perceived as being part of the problem rather than a resource (Mac Ruairc, 2011; Palaiologu, Evangelou, \& Tspakidou, 2011). In certain cases, the school fosters a sense of impotence in the family and a sense of distance that parents associate with frustration and a sense of being judged (Perregaux et al., 2011).

Even though teachers usually emphasize the positive aspects that a good family-school relationship provides (Andonov, 2007; Humbeeck et al., 2006; Pati, 2001), they seem to seek out collaboration from parents only in times of difficulty over disciplinary matters or learning issues (Papazoglou, 1984), the causes of which are often attributed to the family. If middle-class parents are able to make use of a common culture, networks of friends and the type of knowledge that allows them to understand the school system and its language, migrant families and those of a lower socio-economic status have very little information at their disposal regarding the organization of the school, disciplinary practices and so on. Teachers and school personnel tend to take this information for granted, which only aids in strengthening inequalities of already existing knowledge (Lareau, 1987; Useem, 1991, 1992). According to the theory of 'cultural capital', of 'educational reproduction' (Bourdieu, 1996; Bourdieu \& Passeron, 1976) and the sociolinguistic theory of 'elaborated and restricted linguistic codes' (Bernestein, 1975), schools significantly influence students' careers through the use of specific authoritarian patterns types of curricula and authoritarian models that favour social dominant groups.

Schools do not seem to be so efficacious in sharing information with students and parents, especially in high schools; this is not only caused by disorganization, nor by the perception of one's tasks, nor by communication flows that are taken for granted or as shared regarding a framework of knowledge and information, but also by the fact that keeping knowledge to oneself is also a type of power. Directors and teachers can take advantage of the lack of knowledge that 
parents and students have with regards to the school system (Meyer \& Rowan, 1977). Without appropriate knowledge, parents and students can only make small requests, and they are not capable of understanding existing difficulties (Dornbusch \& Glasgow, 1996). However, teachers increasingly feel that they are being watched, and looked at with disapproval and/or criticized by parents.

The relationship with parents is certainly not an easy one. Dealing with families means encountering different types of axiologies, convictions about what educating means, which tasks lie with the school and which with the family, representations of educational functions linked to roles of parents and teachers, all of which bring with them different interpretations of the family-school relationship, as well as of its meaning and the methods to be used. Teachers' most frequent objections concerning active involvement of parents - which can mean their presence in the classroom (Gestwicki, 2007) - can be classified as follows (points a, b and c are from Tizard, Mortimore, \& Burchell, 1981; the last by author):

a) Organizational. Difficulty of carrying out all tasks involved, especially of a bureaucratic nature, which are part of the job and require a lot of time. Sharing of one's own educational activity with parents, the exchange of information, preparation of shared activities, all require a large investment both in terms of energy and time;

b) Professional. Teachers' competences and efficacy of their actions can be weakened by the presence of unprepared parents, by their chatter and unfair requests, and by their lack of respect for teachers' professionalism;

c) Educational. Teachers' educational activity can be effective even when family collaboration does not exist; the inadequacy of families is one of the main difficulties that teachers' have to deal with in their actions; the task assigned to schools is very precise: teaching;

d) Personal. A feeling of personal and professional inadequacy; difficulty in relationships with adults (not feeling prepared for dealings implicit in a collaborative relationship; fear of having of not being up to dealing with tensions and conflicts).

The idea of parental involvement triggers teachers' fears of losing their professional autonomy, their educational-didactic management and authority. INTO (Irish National Teachers Organisation) describes it as such:

[F] ears remain that increasing parental involvement in schools, particularly to the point of partnership and the involvement of parents in the classroom, constitute a threat to professional status and even professional competence. It is argued that professionals and non-professionals 
cannot be partners except in a very loose sense. Partnership has not been proclaimed with the medical professional with whom parents share the health care of children or with the legal profession when cases of law and justice arise. [...] It must also be noted that there are attitudinal and professional difficulties among teachers, many of whom feel threatened by what is seen as parental encroachment in a professional domain (INTO, 1997, pp. 21-26).

Teachers' actions can be seen as two opposing orientations: democratization and corporativism. In trying to obtain financing and in seeing projects approved, teachers rely on parents and participatory members and/or school management, while paradoxically and simultaneously, in order to strengthen one's own position within these participatory organisms and of the school, professional jargon is used, thereby distancing parents (Fernández-Enguita, 1993).

\section{Reasons to Foster Collaboration between Home and School}

The idea that parents are not very interested or poorly motivated in working on a relationship with teachers seems be on the rise. Also gaining ground is the increasingly popular conviction, which has to be confronted, even with lower class and/or less cultured families, is the lack (whether perceived and/or real) of an adequate educational ability, the scarce knowledge of the school system, different concepts of parents' educational role and, above all, of school practices and teachers' actions that do not really encourage the presence of families at school (Deslandes, 2009; González-Falcón \& RomeroMuñoz, 2010; INTO, 1997; Pati, 2008). These are aspects that have been already noted for some time, even in other contexts:

Status variables are not the most important measures for understanding parent involvement. At all grade levels, the evidence suggests that school policies and teacher practices and family practices are more important than race, parent education, family size, marital status, and even grade level in determining whether parents continue to be part of their children's education (Epstein, 1990, p. 109).

Family-school relationships express a complex reality that cannot be reduced simplistically: in each school, there are as many different situations as there are families (and teachers) involved. In each case, when parents and teachers choose to collaborate, things improve for all parties (above all for 
students). The sharing of pedagogical responsibility allows parents and teachers to create energies, identify strategies, and to be a coherent educational model for future generations. Schools need the active participation of parents just as families need the collaboration and support of schools. Teachers and parents know this and when asked, they clearly admit it (Dusi, 2010a, 2011).

Parental support can help reach superior standards in students' educational careers. Awareness of this, however, can only be a starting point for planning and developing a family-school relationship on a regular basis that works in respect of mutual competences and respective territories.

The systemic vision of human relationships and social realities (Bronfenbrenner, 1979) highlights the fact that apart from fostering psycho-social development of children and positively influencing their school performance, there are various benefits that a good family-school relationship brings with it on many levels (Haynes \& Ben-Avie, 1996; Haynes, Gebreyesus, \& Comer, 1993):

a) Teachers. Giving attention to parents requires great energy and involvement, but in doing so teachers acquire important information concerning their students. Knowledge of the socio-cultural context in which they carry out their jobs increases. Deeper understanding of the students' reality lets the teacher intervene more efficaciously both in the climate of the classroom and teaching strategies, so as to improve the teacher's self-efficacy.

b) Parents. Dialogue and dealing with other adults concerning educational dynamics and the growth of children leads to access of new information, to the discovery of other perspectives of interpretation regarding a type of behaviour, a situation or an educational problem. By fostering reflection, this dialogue is a privileged way of keeping up one's own selftraining. Teachers must become an educational point of reference for adults and schools a place of hope for the present and future of parents' children.

c) School. For the institution to deal with parents who are present, involved and committed means having access to resources and energy to invest in improving structures, activities and initiatives, the very processes of teaching. Earning trust and the participation of families requires imagination, commitment, creativity and investment in planning and communications activities, which require training of personnel and institutional change.

d) Community. When the two main educational institutions of family and school collaborate, school becomes a centre of training and social 
promotion, a place in which knowledge is spread and social capital is created. The task of the school is not that of taking on the educational functions of families for itself, nor is it only meant to ask parents the function of checking up on the carrying out of homework. Instead, its duty is to encourage parents to expand their sphere of interest, knowledge and activities so as to be able to carry out its educational function and to become a place that promotes social change. From this perspective, the school is called on to become more flexible, to be culturally sensitive and reactive, and to form a bond with families and the territory ( $c f$. Dewey, 2004).

Caring for students who fill the classroom day after day means gaining knowledge and understanding of their world. The family is their inner territory, their roots, their gaze upon the world and themselves:

Our students (...) never come to school alone. An 'onion' (of layers) comes into the classroom: various layers of knots in their stomachs, fears, worries ... look at them, here they come, the body in development and the family in the knapsack. The lesson can begin only after they have unloaded this weight down and left behind the outside world (Pennac, 2008, p. 55).

If students only need to unload their weight and leave the outside world behind in order to be calm and concentrate on learning tasks, on relationships, mutual expectations and roles that the school reserves for each one of them, then teachers need to understand each student's family, so as to be able to make suitable changes to their own teaching actions until they become efficacious. Meeting parents in order to come to know and recognize them is a decisive part of the professionalism involved in teaching, given the enormous influence parents have over children:

The fundamental equation of teaching - our equivalent to $\mathrm{E}=\mathrm{mc}^{2}-$ the rule which is never wrong is that knowing parents will help understand children (Perboni, 2009, p. 171).

Through sharing, the practice of teaching becomes more efficacious, even if that requires making a great effort. The reasons for collaboration between home and school are based on the benefit for students and the community; they are rooted in the need/possibility to do better, because each new student entrusted to the care of family and school can self-develop and fuel the desire to 'discover the secrets of the world', as in the words of Octavian (10 
years old). Home and school are the space in which the personality of every new student takes form. The gaze of adults, especially parents, teaches children to look at themselves and to see in a certain way, to recognize their uniqueness, to believe in the possibility of their own development, to find their own place in the world, to gain recognition from others, as Andrea, an 11-year-old student, writes. After having worked on Leopardi's poem 'The Lonely Sparrow', the teacher invited students to reflect on their own lives, starting with the prompt: 'Sometimes even I feel sad and misunderstood.' Andrea's reflection took school into consideration, including his scholastic performance and the expectations that parents and teachers have for him. Through his story, the child highlights the influence of school on family relationships, on the parent-child relationship, on the perception that children have of themselves, on their sense of wellbeing within family and school systems and on the possibility of improving things if he commits himself and the energy required by every change.

Luckily it has never gotten so bad that I feel I am suffocating but, especially in this period, my teachers, my parents, my grandparents all think that I am a child who does not exploit my potential. They are always telling me that I have to put my all into everything I do. The problem is that I am aware of this. For example, Marco is able to give his all and for this reason he is the brightest in the class. And the thing that really bugs me is that I could also be the brightest in the class, and therefore I should do it!

Moreover, my parents make me feel sadder when they compare me to my brother because he does better than me in school. In these moments when I suffer, I feel alone, excluded, cast out like the ugly duckling among many beautiful ducks. But maybe it isn't the others who don't understand me, I don't understand myself. Luckily, sometimes, I can change things and I am proud of myself; with a little luck and being only 11 years old, with time I will be able to change! (From the workbook of this primary student, date of composition at school: 22 April 2010. Both the children's quotations - Octavian's and Andrea's - are from research conducted with some teachers in a primary school. The topic of this research is the family seen through children's eyes). 


\section{Family and School: A Multi-level and Complex Relationship}

There are many factors, variables and contexts that compete in the definition of the family-school relationship. Reflecting on the coming together of parents and teachers means facing a complex and articulated reality that combines three different social levels: macro, intermediary and micro, each of which can influence the others (Dusi, 2010c).

Macro Level. The dynamics of a supranational character intertwine as per the means and ends of parent-teacher interaction. In the family/school relationship dynamics permeating all of society have a role. Demographic, socioeconomic and cultural changes of the modern world have their influence on the family-school relationship. There are many dynamics at work in our current times. The most important ones specifically are those related to:

- $\quad$ Cultural poly-centrism. Schools do not have a monopoly on access to knowledge, nor does it represent the prerogative of the élite, not only in the sense of social class, but also of merit and ability. Moreover, the role of school has been decreased by changes in the job market: a diploma or a degree no longer ensures socio-economic progress (Auduc, 2007; Dusi, 2002).

- The multi-ethnic composition of society. Demographic and cultural changes that have taken place in the various European states have also involved school systems. The cultural-linguistic difference today is a basic structural part of school systems, even in those states that underwent outgoing migration flows in the past (Southern Europe). The role of schools and its professionals has transformed to become more complex and difficult (Andonov, 2007; Dusi, 2010b; Talib, 2006).

- The establishment of neoliberal ideology and the decrease in welfare state policies. Individualistic-consumerist orientations identify one of the fundamental criteria in evaluating efficacy of public services through client satisfaction. In the past, education was seen as a collective right. Democratic institutions were expected to guarantee access to schools to everyone. With the introduction of neoliberalism, educational processes have also been reinterpreted through ideas related to market ideologies. Parents are not seen as citizens with a right and duty to educate their children, but rather as clients with the right to choose the school where to enrol their child (Osborn et al., 2003; Ravn, 2005).

In other words, parents as clients and consumers are encouraged to choose among the many offers in the educational market. The idea of 
community in school and in class is fading away. Global competing economies and a dominant market orientation are championing the model of people as consumers of education rather than the producers of education through public policy. [...] these days individual schools are asked by the government to set up their specific profiles. [...]. The setting up of an image or profile for each school is a question of marketing each school's individual identity and reputation in order to attract clients. [...] Schools are being conceived of as 'society's offer' to the parents (Kryger \& Ravn, 2009, pp. 14-15).

Individualism, consumerist attitudes and the decrease in participation that are widespread in Western society have also made their presence felt within school systems, where parents are always less present in terms of cooperation but increasingly active in terms of being aggressive and making demands on teachers. This is why it is necessary to invest in the training of teachers and parents.

Intermediary Level. The two institutions involved are different: family is not school and vice versa.

Even though educational issues and practices appear tangled, it is important to keep clear that families and schools are distinct institutions, situated in different spaces and times of everyday life, comprising particular (physical and social) arrangements, responding to different social and individual needs, and carrying exclusive functions (de Carvalho, 2001, pp. 40-41).

Functions, perspectives, timing of interventions and competences are different. Moreover, on the institutional level, the forms the two institutions may take are different due to normative frameworks and the levels of schools, and how these are structured and interconnected, and due to the model of socially recognized families and to those - which by nature - are present in the territory. In the relationship between the two institutions, the family acts personally for the most part, while schools have an institutional plan. For this reason, since family-school relationships are ones of power, most families are powerless when dealing with schools. Due to this type of asymmetry, it is the school that must promote collaboration with the family.

Even though they have different roles, tasks and perspectives, the institutions of school and family are called on to create a dialogue in order to contribute to the processes of training new generations. They both need each other in order to carry out their task in the best way (Dusi, 2010a). 
Micro Level. The interpersonal level: the parent-teacher relationship. In contemporary society, parents and teachers are called on to take care of education of new generations. This task is to be shared, even if the timing, places and types are different. This is why the family-school relationship is complex: the institutions, powers and perspectives that come together are dual in nature. However, the educational goals of both halves are the same: to offer the best to children, to accompany them in their growth ensuring that they become strong and capable of moving around in the world safely, but each one of these goals take on different meanings that translate into educational processes, strategies and methods that are more or less different between parents and teachers. The difference in perspectives and methods to be used in carrying out educational functions is constituted by the parent-teacher relationship, which is often informed by conflicts of power and values (Henry, 1996).

Research conducted in selected European countries shows that teachers hold a similar opinion of parents (Smit \& Driessen, 2009). Researchers have found that there are certain recurring attitudes among parents as soon as they begin to deal with schools.

Milada Rabusicova (2009) addressed the issues of parents' roles with respect to school with a combination of methods, which led to the drawing up of a questionnaire that was distributed among schools and parental representatives.

Data analysis showed which roles are most often ascribed to parents: the customer; the partner; the source-of-problem; the citizenship role. The customerparent role accounted for by $82 \%$ of answers while the citizenship role was the least represented (18\%). The most significant data, as Rabusicova points out, is the fact that there is no difference between how parents were perceived by school representatives and by parents themselves. In fact, the two different models are not mutually exclusive: every parent adopts behaviours that recall other models.

Many teachers and headmasters will assert with absolute confidence that parents are partners to them on one occasion and that they are customers on another, without being able to differentiate between these dimensions of parents roles. [...]. School documents sometimes treat parents 'preventively' as a potential source of problems, sometimes as customers entitled to a free choice of a school - a choice, however, that is hard to exercise - at other times as citizens with a right to comment on the operation of public institutions and to associate in organizations supporting school (Rabusicova, 2009, p. 25).

The relationship between individual behaviours and social orientations appears significant. The presence at a supranational level (macro) of the 
neoliberal and market orientation is found in parents (micro) who act like clients ( $82 \%$ of answers) in their relationship with an institution which - in accordance with scholastic policies adopted by governments - has appropriated some of the rules of the market and its language (intermediary).

\section{Some Suggestions to Improve the School-Family Relationship}

Schools and their professionals are called upon to deal and dialogue with a myriad of family and personal visions; it is the parents who have the right/duty to accompany children in their processes of growth and learning. Despite the difficulty of the phenomenon in question, it is possible to improve the family-school relationship if:

- $\quad$ taking care of students is the focus of one's actions (Dusi, 2010a);

- teachers have the will to act as a partner to parents and parents to increase their participation;

- $\quad$ teachers give proof of their involvement in the relationship with parents and show their desire to invest in processes of collaboration;

- teachers show openness and are attentive of a relationship with some parents - often from another culture - that is lacking or different in the awareness that what is missing may not be due to a lack of interest, but to a different conceptual framework of expectations and norms in the family-school relationship (Huss-Keeler, 1997);

- teachers are prepared to continue collaboration with parents actively, to ask their opinions and points of views (through interviews, consultations, questionnaires) (Smit \& Driessen, 2009);

- there is a solid relationship of collaboration among teachers. The practice of sharing ideas, opinions and situations with colleagues regarding students and families allows for a conceptualization of relationships, to give the correct meaning to words used and to adopt more suitable strategies for each family. Teachers become an element of strength, of professional growth and support, all of which are elements that influence communication flows with parents and collaborative relationships with families positively (Dusi, 2010a);

- the implicit culture of the school is made explicit: teachers must ensure that migrant parents (and others) understand the function of school and what the school's expectations of them are (Bernhard \& Freire, 1999);

- tools are created to welcome families, both at the institutional level (normative, protocols, documentation, spaces, etc.), and at the interpersonal 
level between teachers and parents (flexibility in timing of parent-teacher interviews and meetings - cf. Lopez et al., 2001; communication styles, motivating collaboration, recognition of parents' roles etc.). A welcoming atmosphere is a crucial moment in the family-school relationship (especially for migrant families, $c f$. Perregaux, 2008);

- $\quad$ investments are made in participatory communication processes with families: from parent-teacher interviews ( $c f$. from the joint action model (Ravn, 2011) to the homework diary and school reports; Lahaye, Pourtois, \& Desmet, 2009);

- institutions promote the educational competences and resources of parents.

These proposals call on the responsible politicians for economic funding of the school system, from its organization to methods of teaching training. This latter is a fundamental dimension for the evolution of the family-school relationship based on collaboration, with effects for each person involved and the entire community. The role of teachers in the family-school relationship - by nature - is central, because parents play a crucial role in the education of their children. This does not meaning having to ask whether one has to foster family relationships, but to ask what forms these relationships should have, which model to foster as a teacher and as an institution located in a territorial context.

The way schools care about children is reflected in the way schools care about the children's families. If educators view children simply as students, they are likely to see the family as separate from the school. That is, the family is expected to do its job and leave the education of children to the schools. If educators view students as children, they are likely to see both the family and the community as partners with the school in children's education and development (Epstein, 2009, p. 9).

\section{Discussion and Conclusions}

The analysis of the literature carried out in the present study makes reference to a limited amount of research, as it is also based on the work of other researchers. This is an exploratory reflection that requires further indepth study in the field. Moreover, this study identifies selected baselines that inform the family-school relationship, beyond those of each particular nation, by highlighting influences of certain socio-economic and cultural orientations of complex societies (neoliberalism, migration, etc.) and, as such, it goes toward 
confirming the hypothesis that, in our times, the coming together of the two main educational institutions and their agents is a complex situation by its very nature, which goes beyond the social-cultural and legislative differences of where this encounter takes place.

\section{References}

Andonov, L. (2007). Teacher-parent interaction and frames of the conversation in the students' consultation discussions. Research Report 280 . Helsinki: University of Helsinki, Faculty of Behavioural Science, Department of Applied Science of Education.

Auduc, J.-L. (2007). Les relations parents-enseignant à l'école primaire. Creteil: Scérén.

Baker, D. P., \& Stevenson, D. L. (1986). Mothers' strategies for children school achievement:

Managing the transition to high school. Sociology of Education, 59, 156-166.

Bastiani, J. (1993). Parents as partners. Genuine progress or empty rethoric? In P. Munn (Ed.), Parents and Schools (pp. 104-116). London: Routledge.

Bernestein, B. (1975). Class code and control. London: Routledge \& Kegan Publ.

Bernhard, J. K, \& Freire, M. (1999). What is my child learning at elementary school? Culturally contested issues between teachers and Latin American families. Canadian Ethnic Studies, 31(3), 72-95.

Bourdieu, P. (1986). The forms of capital. In J.G. Richardson (Ed.), Handbook of theory and research for the sociology of education (pp. 241-258). New York: Greenwood Press.

Bourdieu, P., \& Passeron, J. C. (1976). Reproduction in education, society and culture. London: Sage. Bronfenbrenner, U. (1979). The Ecology of Human Development. Cambridge: Harvard University Press.

Carvalho, M. E. P. de (2001). Family-School relations: A critique of parental involvement in schooling. Mahwah, NJ: Lawrence Erlbaum Associates.

Casanova, U. (1996). "Parent involvement: A call for prudence". Educational Researcher, 25, 30-32. Comer, J. P. (1980). School power: Implications of an intervention project. New York: The Free Press. Comer, J. P. (1986). Parent Participation in the schools. Phi Delta Kappa, 67, 442-446.

Comer, J. P. (1988). Educating poor minority children. Scientific American, 259(5), 42-48. Dauber, S. L., \& Epstein, J. L. (1989). Parents attitudes and practices of involvement in inner-city elementary and middle schools. Baltimore Johns Hopkins University: Center for Research on Elementary and Middle Schools.

Deslandes, R. (Ed.) (2009). International perspectives on contexts, Communities and evaluated innovative practices. Family-school-community partnerships. New York: Routledge.

Dewey, J. (2004). Democrazia ed educazione. Milano: Sansoni.

Dornbusch, S. M., \& Glasgow, K. L. (1996). The Structural Context of Family-School Relations. In A. Booth \& J. Dunn, Family-School Links. How Do They Affect Educational Outcomes? (pp. 35-44).

Mahwah, NJ: Lawrence Erlbaum Associates. 
Dusi, P. (2002). Une coopération antinomique. Le cas italien. Revue Internationale déducation, 31, $39-50$.

Dusi, P. (2010a). Tessere alleanze educative. In L. Mortari (Ed.), Dire la pratica. La cultura del fare scuola (pp. 293-304). Milano: Bruno Mondadori.

Dusi, P. (2010b). Il dire dei docenti. Analisi dei risultati della ricerca qualitativa a Verona. In A.

Portera, P. Dusi \& B. Guidetti (Eds.), Leducazione interculturale alla cittadinanza. La scuola come laboratorio (pp. 97-112). Roma: Carocci.

Dusi, P. (2010c). Tra casa e scuola: uno sguardo in Europa. Paper presented at the National Conference

"Rapporto scuola-famiglia. Istanze sociali e questioni educative" 29-3o November 2010. Brescia:

Università Cattolica del Sacro Cuore.

Dusi, P. (2011). Il rapporto scuola-famiglia in Italia. Alla ricerca di alleanze educative possibili. In P.

Dusi \& L. Pati (Eds.), Corresponsabilità educativa. Scuola e famiglia nella sfida multiculturale: una prospettiva europea (pp. 49-88). Brescia: La Scuola.

Eccles, J. S., \& Harold, R. D. (1996). Family Involvement in Children's and Adolescents' Schooling. In A. Booth \& J. Dunn, Family-School Links. How Do They Affect Educational Outcomes? (pp. 3-34).

Mahwah, NJ: Lawrence Erlbaum Associates.

Epstein, J. L. et al. (2009). School, Family, and Community Partnerships. Your Handbook for Action.

Thousand Oaks: Corwin Press.

Epstein, J. L. (1986). Parents' reactions to teacher practices of parent involvement. The Elementary

School Journal, 86, 277-294.

Epstein, J. L. (1990). School and family connections: Theory, research, and implication for integrating sociologies of education and family. In D. G. Unger \& M. B. Sussman (Eds.), Families in community settings: Interdisciplinary perspective (pp. 103-113). New York: Haworth Press.

Fernández-Enguita, M. (1993). La profesión docente y la comunidad escolar: crónica de un desecuentro. Madrid: Morata.

Foucault, M. (1998). Archivio Foucault 3. Estetica dellesistenza, etica, politica. Milano: Feltrinelli.

Gayet, D. (1999). Lécole contre les parents. Paris: INRP.

Gestwicki, C. (2007). Home, school, and community relations. Thomson: New York.

González-Falcón, I., \& Romero-Muñoz, A. (2010). La integración de las familias inmigrantes en la comunidad educativa. Educación y Diversidad. Revista Interuniversitaria de Investigación sobre Discapacidad e Interculturalidad, 2(4), 105-116.

González-Falcón, I., \& Romero-Muñoz, A. (2011). La relazione scuola-famiglia in Spagna. Nuove sfide nella società multiculturale. In P. Dusi \& L. Pati (Eds.), Corresponsabilità educativa. Scuola e famiglia nella sfida multiculturale: una prospettiva europea (pp. 227-267). Brescia: La Scuola. Haynes, N. M., Gebreyesus, S., \& Comer, J. P., (1993). Selected case studies of national Implementation of the School Development Program. New Haven: Yale Child Study Center.

Haynes, N. M., \& Ben-Avie, M. (1996). Parents as Full Partners in Education. In A. Booth \& J. Dunn, Family-School Links. How Do They Affect Educational Outcomes? (pp. 45-55). Mahwah, NJ: Lawrence Erlbaum Associates. 
Henry, M. E. (1996). Parents-school collaboration: Feminist organizational structures and school leadership. Albany: State University of New York Press.

Honneth, A. (1992). Kampf um Anerkennung. Grammatik Sozialer Konflikte. Frankfurt am Main: Suhrkamp Verlag.

Humbeeck, B., Lahaye, W., Balsamo, A., \& Pourtois, J.-P. (2006). Le partenariat entre lécole et la famille: un projet de co-éducation entre les différents acteurs de l'éducation. Université de MonsHainaut: Rapport d’Activité, C.E.R.I.S..

Huss-Keeler, R. L. (1997). Teacher perception of ethnic and linguistic minority parental involvement and its relationship to children's language and literacy learning: A case study. Teaching and Teacher Education, 13(2), 171-182.

INTO (1997). Parental involvement: Possibilities for Partnership. Dublin: Into.

Kryger, N., \& Ravn, B. (2009). Homework in Denmark: What kind of links between family and school? In R. Deslandes (Ed.), International Perspectives on Student Outcomes and Homework.

Family-School-Community Partnerships (pp. 7-24). London: Routledge.

Lahaye, W., Pourtois, J.-P., \& Desmet, H. (2009). The challenge of co-education in a disadvantage context. In R. Deslandes (Ed.), International perspectives on contexts, Communities and evaluated innovative practices. Family-school-community partnerships (pp. 82-94). New York: Routledge. Lareau, A. (1987). Social class differences in family-school relationships: The importance of cultural capital. Sociology of Education, 6o, 73-85.

Lopez, G. R., Scribner, J. D., \& Mahitivanichcha, K. (2001). Redefining parent involvement: Lessons from high-performing migrant impacted schools. American Educational Research Journal, $38(2)$, $253-288$.

Mac Ruairc, G. (2011). "No parents beyond this point”. Una riflessione critica sulla partecipazione parentale nella scuola primaria in Irlanda. In P. Dusi \& L. Pati (Eds.), Corresponsabilità educativa. Scuola e famiglia nella sfida multiculturale: una prospettiva europea (pp. 141-172). Brescia: La Scuola. Meyer, J. W., \& Rowan, B. (1977). Institutional organization: Formal structure as myth and ceremony. American Journal of Sociology, 83, 340-363.

Migeot-Alvarado, J. (2002). Un marriage force? Les parents et lécole en France. Revue Internationale d'Éducation, 31, 51-63.

Osborn, M., Broadfoot, P., McNess, E., Planel, C., Ravn, B., \& Triggs, P. (2003). A world of difference? Comparing learners across Europe. Maidenhead: Open University Press.

Palaiologou, N., Evangelou, O., \& Tsapakidou, A. (2011). Le famiglie immigrate trovano ascolto negli spazi scolastici? Il caso della Grecia. In P. Dusi \& L. Pati (Eds.), Corresponsabilità educativa. Scuola e famiglia nella sfida multiculturale: una prospettiva europea (pp. 269-299). Brescia: La Scuola. Papazoglou, N. (1984). School-family relations: Teachers, parents and pupils'rights. Athens: Ed. Epikerotita.

Pati, L. (2001). Famiglia e scuola per l'educazione: dal partecipare al cooperare. La Famiglia, 205, $15-26$.

Pati, L. (2008). La corresponsabilità educativa tra docenti e genitori. La Famiglia, 244, 22-29. 
Pennac, D. (2008). Diario di scuola. Milano: Feltrinelli.

Perboni, G. (2009). Perle ai porci. Milano: Mondolibri.

Perregaux, C. (2008). 26 façon d'accueillir. Ville-école-intégration, 153, 57-67.

Perregaux, C., Changkakoti, N., Gremion, M., \& Hutter, V. (2011). Famiglie migranti in cerca di dialogo con l'istituzione scolastica. In P. Dusi \& L. Pati (Eds.), Corresponsabilità educativa. Scuola e famiglia nella sfida multiculturale: una prospettiva europea (pp. 357-381). Brescia: La Scuola.

Rabusicová, M. (2009). Family-school partnership in theory and practice of the Czech schools: Conflict between ideal and reality. In R. Deslandes (Ed.), International perspectives on contexts, Communities and evaluated innovative practices. Family-school-community partnerships (pp. 21-36).

New York: Routledge.

Ravn, B. (2005). An ambiguous relationship. Challenges and contradictions in the field of familyschool-community partnership. Questioning the discourse of partnership. In R. A. Martinez-

Gonzales et al., Family-school community partnerships merging into social development (pp. 435-475).

Oviedo: GrupoSM.

Ravn, B. (2011). Le relazioni casa-scuola in Danimarca. In P. Dusi \& L. Pati (Eds.), Corresponsabilità educativa. Scuola e famiglia nella sfida multiculturale: una prospettiva europea (pp. 89-111). Brescia:

La Scuola.

Smit, F., \& Driessen, G. (2009). Creating effective family-school partnerships in highly diverse contexts. Building partnership models and constructing parent typologies. In R. Deslandes (Ed.), International perspectives on contexts, Communities and evaluated innovative practices. Family-schoolcommunity partnerships (pp. 64-81). New York: Routledge.

Swap, S. A. (1993). Developing home-school partnership. New York: Teachers College Press.

Talib, M.-T. (Ed.) (2006). Diversity: A Challenge for Education. Turku: Finnish Educational Research Association.

Tizard, B., Mortimore, J., \& Burchell, B. (1981). Involving Parents in Nursery and Infant Schools. London: Grant McIntyre.

Useem, E. L. (1991). Student selection into course sequences in mathematics: The impact of parental involvement and school policies. Journal of Research on Adolescence, 1(3), 231-250. Useem, E. L. (1992). Middle schools and math groups: Parents' involvement in children's placement. Sociology of Education, 65, 263-279. 


\section{Biographical note}

Paola Dusi, PhD in Pedagogy. Senior Researcher and Professor of Social and Intercultural Pedagogy and Pedagogy of the Family, at the University of Verona, Department of Philosophy, Pedagogy and Psychology. Member of the Center for Intercultural Studies - University of Verona and of the Center for Family Studies of Catholic University in Brescia (Italy). Member of PhD Committee at the Verona University, Faculty of Educational Science. Main research areas are the relationship between parents, children and teachers; family education; immigrant families and teachers training. 